http://www.pakjas.com.pk

\title{
APPLICATION OF NAA AND BA IN CHEMICAL THINNING OF SOME COMMERCIAL CULTIVARS OF APPLE
}

\author{
Gordana Šebek* \\ Biotechnical faculty, University of Montenegro, Ul. Mihaila Lalica br. 181000 Podgorica, Montenegro. \\ "Corresponding author's e-mail: sebek@t-com.me
}

\begin{abstract}
This paper presents the fruit thinning response to NAA and BA plant regulators of apple cultivars 'Prima', 'McIntosh' and 'Jonathan'. The experiment was designed to evaluate the effects of NAA applied at three concentrations, 15, 20 and $30 \mathrm{ppm}$, and BA + NAA combinations (BA- 60, 100, 120 or $140 \mathrm{ppm}+$ NAA $5 \mathrm{ppm}$ ) for fruit thinning of the assessed apple cultivars. All the applied treatments with NAA and BA + NAA adequately thinned fruits of 'McIntosh' and 'Jonathan' cultivars, whereas application of NAA at the concentration of 20 and $30 \mathrm{ppm}$ and combined treatment of BA $140 \mathrm{ppm}+$ NAA 5 ppm were effective fruit thinners for 'Prima' cultivar. In terms of the average fruit weight and number of fruits categorized as large $(>75 \mathrm{~mm}$ or $>65 \mathrm{~mm}$ ), as well as from the aspect of fruit number per trunk cross-sectional area, the variant of treatment with BA $140 \mathrm{ppm}$ + NAA 5 ppm was the most effective on 'McIntosh' and 'Prima' cultivars, whereas BA 100 ppm + NAA 5 ppm had the best effect on 'Jonathan' cultivar.
\end{abstract}

Keywords: Naphthaleneacetic acid, benzyladenine, chemical fruit thinning, apple

\section{INTRODUCTION}

For the fresh market of apple fruits, fruit size, appearance, flavor, firmness and storability are of main interest. The growers therefore, have to focus orchard practices to satisfy these market demands in order to produce high quality fruit consistently at maximum yields. It is impossible to maximize all quality factors simultaneously, because there are positive and negative interrelations among them (Link, 2000). Chemical thinning of apple fruits is extremely important cultural practice in the profitable fruit production. The labor costs required for manual fruit thinning are reduced, but at the same time fruit size and quality are increased. Chemical thinning also provides a good yield potential for the following growing season (Yuan and Greene, 2000; Greene, 2002; Petracek and Silverman, 2003). Apple flower buds become initiated 30 to 40 days after blooming, a period when gibberellins (GA) from developing seeds in growing fruits inhibit floral initiation (Ramirez et al., 2004). Because of this, fruit thinning should be performed within 28 days after full bloom to achieve a good fruit size and high return bloom (Kolke et al., 2003).

Naphthalene-1-acetic acid (NAA) is one of the most commonly used compounds for chemical thinning, although there are different data about its effectiveness, which can be partly explained by weather conditions, primarily temperature, and the sensitivity of the variety (Wertheim, 2000). Stopar (2002) states that the effectiveness of chemical thinning on the variety Golden Delicious with the compounds based on NAA does not depend directly on the concentration of NAA. This fact, does not diminish the NAA effectiveness of fruit thinning, because NAA is the most important and the most frequently applied plant bioregulator in practice. Bound (2001) reported that high concentrations and later application of NAA has a negative effect on fruit size. Benzyladenine (BA) is steadier and more effective compound for apple fruit thinning because, despite of the reduction of yields, it increase fruit size and provide feedback flowering (Greene et al., 1990; Ferree, 1996). Link (2000) has noted that the use of BA increased the fruit size even in the absence of fruit thinning. In terms of the number of fruits per each branchlet, fruit weight, fruit diameter and yield height the best results in the chemical thinning of apple cultivar Golden Delicious were obtained using BA in the concentration of $200 \mathrm{mg} / 1$ (Milic et al., 2011). Increasing the size of the fruit BA realizes through stimulation of cell division (Wismer and Proctor, 1995). Greene (1993) points out that the application of BA was the most effective when the central apple fruit was $10 \mathrm{~mm}$ in diameter. Thinning with BA gave promising results in cultivar 'Golden Delicious Clone B'. Further research of BA based thinning chemicals and their effects on fruit quality has be done in environmental conditions of Serbia (Keserovic et al., 2008).

The combined use of compounds for the thinning may result in more intensive thinning compared to a single application of plant regulators (Wertheim, 1997). Bukovac et al. (1994) reported that the combination of NAA and BA leads to excessive fruit thinning of 'Empire' cultivar. In contrast, the combined application of NAA and BA ("tank mix spray") for the cultivars 'Gala' and 'Golden Delicious' had no cumulative effect compared to single applications of these compounds (Stopar, 2002). Good results in terms of 
increasing the weight and diameter of fruits of 'Golden Delicious Clone B' were achieved using a combination of BA + "Dirager" (3.3\% NAA) (Vračević et al., 2008). With the cultivar 'Summerred', a combination of the two compounds, leads to an increase in fruit size (Stopar and Lokar, 2003), and inhibits the development of the fruit in the cultivar 'Delicious RedChief' and the cultivar 'Fuji' (Stopar and Tojnko, 2005). Marini (2002) states that it is very difficult to adequately apply the processs of thinning in spur varieties such as 'Red Delicious', and that the use of NAA obtained satisfactory results in terms of fruit size and share of small fruits. The aim of this study was to examine the efficacy of two plant regulators, NAA and BA, alone or in combination, on the level of chemical thinning of apple fruit in three cultivars 'McIntosh', 'Jonathan' and 'Prima'.

\section{MATERIALS AND METHODS}

The experiment was conducted during 2010 to 2013, in apple orchards on private land of Šebek family, Bijelo Polje, Montenegro. The trees were five years old, grafted on clonal rootstock 'MM 106'. The trees were planted at a distance of $4 \times 4 \mathrm{~m}$. Applied cultivation form is pyramidal crown. In apple orchards standard cultural practices were been applied. The experiment design was a completely randomized block system with three replications, where each individual tree was one repetition. In order to determine the yield potential of varieties, we measured the diameter of each tree trunk at 20 $\mathrm{cm}$ above the site of grafting. The selected trees within each variety were of consistent vigor and abundance of flowering (approximately 125-145 flowers per tree). For fruit thinning applied treatments were as follows:

1. NAA $15 \mathrm{ppm}$ (4 ml Dirager / 101 of water);

2. NAA $20 \mathrm{ppm}(5,4 \mathrm{ml}$ Dirager / 101 of water $)$;

3. NAA $30 \mathrm{ppm}$ (8,1 ml Dirager / 101 of water);

4. BA $60 \mathrm{ppm}(15 \mathrm{ml}$ Gerba $4 \mathrm{LG} / 101$ of water $)+$ NAA 5 ppm (1,3 ml Dirager);

5. BA $100 \mathrm{ppm}(25 \mathrm{ml}$ Gerba $4 \mathrm{LG} / 10$ of water $)+$ NAA 5 ppm (1,3 ml Dirager);

6. BA $120 \mathrm{ppm}$ (30 ml Gerba 4 LG / 101 of water $)+\mathrm{NAA}$ 5 ppm (1,3 ml Dirager);

7. BA 140 ppm (35 ml Gerba 4 LG / 101 of water $)+$ NAA 5 ppm (1,3 ml Dirager);

8. Control- no treatment.

Preparations used in the thinning of tested apple cultivars have commercial name "Dirager" and "Gerba 4 LG" and are produced by the producer L. Gobbi, Italy. In all treatments, to the solution was added $1 \mathrm{ml} \mathrm{L}^{-1}$ of surfactant "Belol". Treatment was performed with the use of back atomizer "Villager D-25", with a volume of 12L tank. Treatments were applied with an average of $0.5 \mathrm{~L}$ of solution per tree.

The treatments were carried out when the central fruit in the cluster reached a value of fruit diameter of 8-10 mm. Average sample of 10 fruits was taken from each tree at the stage of physiological maturity. Weight, height, and width of fruits were determined by conventional morphometric methods on a sample of 50 fruits. In all the cultivars the following parameters were examined: number of fruits per tree, number of fruits per unit cross-sectional area of the trunk (number of fruits, $\mathrm{cm}^{-2}$, total yield $\left(\mathrm{kg}\right.$ tree $\left.{ }^{-1}\right)$, yield efficiency $\left(\mathrm{kg} \cdot \mathrm{cm}^{-2}\right)$, yield and number of fruits with a diameter $>75 \mathrm{~mm}$ (for varieties 'McIntosh' and 'Jonathan'), yield and number of fruits with a diameter $>65 \mathrm{~mm}$ ('Prima'), average fruit weight ( $g$ ) and the average size of the fruit determined by fruit shape index (fruit shape index is equal to the quotient of fruit height $(\mathrm{mm})$ and fruit width $(\mathrm{mm})$ ). The differences between the means of treatments were evaluated using LSD test at $\mathrm{P}<0.05$ and $\mathrm{P}<0.01$.

With the cultivar 'Prima' the fruits were classified as $65 \mathrm{~mm}$ as opposed to the classification of the cultivars McIntosh and Jonathan $(75 \mathrm{~mm})$. It was done purposefully because cultivar Prima belongs to the category of varieties with medium-large fruit and cultivars 'McIntosh' and 'Jonathan' belong to the category of varieties with large fruit.

\section{RESULTS}

This research tested the effect of NAA and BA, alone or combined, on fruit thinning in apple cultivars 'McIntosh', 'Jonathan' and 'Prima'.

Apple cv. Prima: The application of NAA did not affect significantly on the increase of fruit weight in the cultivar 'Prima' (Table 1). Significantly increased fruit weight resulted in the combined use of BA + NAA (treatments 4, 6 and 7), and its yield was not statistically different from the control treatment. Treatments 6 (BA 120 ppm + NAA 5 ppm) and 7 (BA $140 \mathrm{ppm}+$ NAA $5 \mathrm{ppm}$ ), in addition to fruit weight increased and led to a statistically significant increase of the fruit shape index.

A significant reduction in the yield of 'Prima' apple fruits was found in NAA 20 ppm treatment. Significantly higher yield compared to the control was determined by combined application of BA 100 ppm + NAA 5 ppm. Significantly lower total number of fruits per trunk cross-sectional area was found after a single application of NAA at the concentration of 20 or $30 \mathrm{ppm}$, and after combined application of $140 \mathrm{ppm}$ BA + NAA 5 ppm. Treatment with BA 100 ppm + NAA 5 ppm resulted in significantly higher total number of fruits per trunk cross-sectional area.

Number of fruits with a diameter $>65 \mathrm{~mm}$ in treatments 1 and 2 as well as yield of fruits with a diameter $>65 \mathrm{~mm}$ in treatment 2 were statistically similar in comparison to control. All other treatments resulted in a statistically significant increase in the number and yield of fruits with a diameter $>65$ mm compared to the control (Table 2). The effect of thinning of fruits of 'Prima' was not observed after application of combined treatment BA 100 ppm + NAA 5 ppm, resulting in a large number of fruits per trunk cross-sectional area and 
Table 1. Pomological properties, yield and yield efficiency of 'Prima' apple trees after the application of fruit thinning agents (average 2010-2013).

\begin{tabular}{lcccccc}
\hline Treatment & $\begin{array}{c}\text { Fruit } \\
\text { weight }(\mathbf{g})\end{array}$ & $\begin{array}{c}\text { Fruit } \\
\text { height }(\mathbf{m m})\end{array}$ & $\begin{array}{c}\text { Fruit width } \\
(\mathbf{m m})\end{array}$ & $\begin{array}{c}\text { Fruit shape } \\
\text { index }\end{array}$ & $\begin{array}{c}\text { Yield (kg•• } \\
\text { tree-1) }\end{array}$ & $\begin{array}{c}\text { Yield efficiency } \\
\left(\mathbf{k g}^{-1} \mathbf{~ m}^{-2}\right)\end{array}$ \\
\hline NAA 15 ppm & 120.1 & 54.8 & 65.3 & 0.84 & 13.5 & 2.1 \\
NAA 20 ppm & 135.3 & 59.5 & 68.0 & 0.87 & 6.8 & 1.1 \\
NAA 30 ppm & 139.0 & 58.0 & 69.0 & 0.84 & 10.9 & 1.7 \\
BA 60 ppm + NAA 5ppm & 148.3 & 65.1 & 75.9 & 0.85 & 13.7 & 2.1 \\
BA 100 ppm + NAA 5 ppm & 109.0 & 55.1 & 63.5 & 0.86 & 16.2 & 2.6 \\
BA 120 ppm + NAA 5 ppm & 141.8 & 59.4 & 64.6 & 0.91 & 12.9 & 2.0 \\
BA 140 ppm + NAA 5 ppm & 156.8 & 67.0 & 74.5 & 0.90 & 12.2 & 1.9 \\
Control & 121.2 & 55.7 & 64.0 & 0.87 & 12.5 & 2.0 \\
LSD 0.05 & 18.1 & 5.09 & 6.48 & 0.019 & 0.50 & 0.22 \\
LSD 0.01 & 21.3 & 7.53 & 8.50 & 0.022 & 0.74 & 0.35 \\
\hline
\end{tabular}

Table 2. Final fruit number per trunk cross-sectional area, and fruit number, yield and yield efficiency of $>65 \mathrm{~mm}$ fruits of 'Prima' apple trees after the application of fruit thinning agents (average 2010-2013).

\begin{tabular}{|c|c|c|c|c|}
\hline Treatment & $\begin{array}{c}\text { Fruit number per trunk } \\
\text { cross- sectional area }\end{array}$ & $\begin{array}{c}\text { Fruit number } \\
>65 \mathrm{~mm}\end{array}$ & $\begin{array}{l}\text { Yield of }>65 \mathrm{~mm} \\
\text { fruits }\left(\mathrm{kg} \cdot \text { tree }^{-1}\right)\end{array}$ & $\begin{array}{l}\text { Yield efficiency of } \\
>65 \mathrm{~mm}\left(\mathrm{~kg}^{\circ} \mathrm{cm}^{-2}\right)\end{array}$ \\
\hline NAA $15 \mathrm{ppm}$ & 17.1 & 29 & 5.9 & 0.9 \\
\hline NAA $20 \mathrm{ppm}$ & 10.0 & 24 & 4.7 & 0.8 \\
\hline NAA $30 \mathrm{ppm}$ & 13.4 & 37 & 7.1 & 1.1 \\
\hline BA $60 \mathrm{ppm}+\mathrm{NAA} 5 \mathrm{ppm}$ & 15.2 & 63 & 10.8 & 1.6 \\
\hline BA $100 \mathrm{ppm}+$ NAA $5 \mathrm{ppm}$ & 21.1 & 35 & 6.1 & 0.9 \\
\hline BA $120 \mathrm{ppm}+$ NAA $5 \mathrm{ppm}$ & 15.0 & 46 & 9.0 & 1.3 \\
\hline BA $140 \mathrm{ppm}+$ NAA $5 \mathrm{ppm}$ & 13.4 & 60 & 12.3 & 1.8 \\
\hline Control & 16.1 & 25 & 4.4 & 0.7 \\
\hline LSD 0,05 & 2.45 & 4.8 & 0.59 & 0.25 \\
\hline LSD 0,01 & 4.15 & 5.5 & 1.45 & 0.32 \\
\hline
\end{tabular}

Table 3. Pomological properties, yield and yield efficiency of 'McIntosh'apple trees aafter the application of fruit thinning agents (average 2010-2013).

\begin{tabular}{lcccccc}
\hline \multicolumn{1}{c}{ Treatment } & $\begin{array}{c}\text { Fruit } \\
\text { weight }(\mathbf{g})\end{array}$ & $\begin{array}{c}\text { Fruit height } \\
(\mathbf{m m})\end{array}$ & $\begin{array}{c}\text { Fruit width } \\
(\mathbf{m m})\end{array}$ & $\begin{array}{c}\text { Fruit shape } \\
\text { index }\end{array}$ & $\begin{array}{c}\text { Yield (kg• } \\
\text { tree-1) }\end{array}$ & $\begin{array}{c}\text { Yield } \\
\text { efficiency } \\
\left(\mathbf{k g}^{-1} \mathbf{c m}^{-2}\right)\end{array}$ \\
\hline NAA 15 ppm & 162.6 & 64.2 & 81.3 & 0.79 & 5.5 & 0.9 \\
NAA 20 ppm & 177.6 & 65.4 & 78.4 & 0.83 & 3.5 & 0.6 \\
NAA 30 ppm & 169.7 & 67.3 & 82.5 & 0.82 & 3.2 & 0.6 \\
BA 60 ppm + NAA 5ppm & 161.9 & 64.3 & 79.2 & 0.81 & 5.5 & 0.9 \\
BA 100 ppm + NAA 5ppm & 169.6 & 66 & 81.2 & 0.81 & 5.7 & 0.9 \\
BA 120 ppm + NAA 5ppm & 198.7 & 70.1 & 83.3 & 0.84 & 4.7 & 0.8 \\
BA 140 ppm + NAA 5ppm & 194.7 & 71.6 & 86.2 & 0.83 & 5.1 & 0.8 \\
Control & 154.5 & 64.0 & 79.0 & 0.81 & 6.5 & 1.1 \\
LSD 0,05 & 17.4 & 6.01 & 7.25 & 0.014 & 0.48 & 0.12 \\
LSD 0,01 & 20.3 & 8.95 & 9.45 & 0.018 & 0.65 & 0.18 \\
\hline
\end{tabular}

significantly lowered average fruit weight in comparison to trees without the use of chemical thinning.

Apple cv. McIntosh: The application of all treatments (individual application of NAA and combination of NAA + BA) in thinning cultivar 'McIntosh' has led to an increase in fruit weight (Table 3). Significant increase of fruit weight was determined after a single application of NAA at $20 \mathrm{ppm}$ (treatment 2), and after combined application of BA + NAA (treatments 6 and 7). Treatment 2 (NAA $20 \mathrm{ppm}$ ) and treatment 6 (BA $120 \mathrm{ppm}+\mathrm{NAA} 5 \mathrm{ppm})$ resulted in a statistically significant increase in the index of fruit shape. Yield, yield efficiency and the total number of fruits per trunk cross-sectional area in all the treatments were significantly lower than in untreated trees. However, the treatments which 
Table 4. Final fruit number per trunk cross-sectional area, and fruit number, yield and yield efficiency of $>75 \mathrm{~mm}$ fruits of 'McIntos' apple trees after the application of fruit thinning agents (average 2010-2013).

\begin{tabular}{lcccc}
\hline Treatment & $\begin{array}{c}\text { Fruit number per } \\
\text { trunk cross- } \\
\text { sectional area }\end{array}$ & $\begin{array}{c}\text { Fruit number } \\
\mathbf{7 6 5 m m}\end{array}$ & $\begin{array}{c}\text { Yield of } \mathbf{~ 6 5 m m} \\
\text { fruits }\left(\mathbf{k g} \cdot \mathbf{t r e e}^{-\mathbf{1}}\right)\end{array}$ & $\begin{array}{c}\text { Yield efficiency of } \\
\mathbf{> 6 5 m m}\left(\mathbf{k g}^{-} \mathbf{~ c m}^{-2}\right)\end{array}$ \\
\hline NAA 15 ppm & 6.1 & 27 & 4.0 & 0.6 \\
NAA 20 ppm & 3.9 & 15 & 1.8 & 0.2 \\
NAA 30 ppm & 3.9 & 18 & 2.4 & 0.4 \\
BA 60 ppm + NAA 5ppm & 2.9 & 18 & 2.1 & 0.3 \\
BA 100 ppm + NAA 5ppm & 6.1 & 18 & 2.6 & 0.4 \\
BA 120 ppm + NAA 5ppm & 4.5 & 24 & 4.2 & 0.6 \\
BA 140 ppm + NAA 5ppm & 4.8 & 22 & 4.9 & 0.7 \\
Control & 7.2 & 15 & 1.8 & 0.3 \\
LSD 0,05 & 0.75 & 3.8 & 0.28 & 0.10 \\
LSD 0,01 & 1.4 & 4.3 & 0.45 & 0.16 \\
\hline
\end{tabular}

Table 5. Pomological properties, yield and yield efficiency of 'Jonathan' apple trees after the application of fruit thinning agents (average 2010-2013).

\begin{tabular}{lcccccc}
\hline Treatment & $\begin{array}{c}\text { Fruit } \\
\text { weight }(\mathbf{g})\end{array}$ & $\begin{array}{c}\text { Fruit height } \\
(\mathbf{m m})\end{array}$ & $\begin{array}{c}\text { Fruit width } \\
(\mathbf{m m})\end{array}$ & $\begin{array}{c}\text { Fruit shape } \\
\text { index }\end{array}$ & $\begin{array}{c}\text { Yield (kg• } \\
\left.\text { tree }^{-1}\right)\end{array}$ & $\begin{array}{c}\text { Yield } \\
\text { efficiency } \\
\left(\mathbf{k g}^{-2} \mathbf{c m}^{-2}\right)\end{array}$ \\
\hline NAA 15 ppm & 177.8 & 66.2 & 73.4 & 0.90 & 7.5 & 1.2 \\
NAA 20 ppm & 205.4 & 73.8 & 84.0 & 0.88 & 7.7 & 1.3 \\
NAA 30 ppm & 223.3 & 76.1 & 82.2 & 0.93 & 6.4 & 1.1 \\
BA 60 ppm +NAA 5ppm & 199.6 & 70.4 & 79.0 & 0.89 & 7.0 & 1.2 \\
BA 100 ppm +NAA 5ppm & 221 & 73.7 & 81.8 & 0.90 & 9.0 & 1.5 \\
BA 120 ppm +NAA 5ppm & 229.1 & 73.4 & 79.0 & 0.93 & 8.8 & 1.4 \\
BA 140 ppm +NAA 5ppm & 219.1 & 76.4 & 83.6 & 0.91 & 3.8 & 0.6 \\
Control & 145.5 & 59.9 & 68.9 & 0.87 & 10.5 & 1.6 \\
\hline LSD 0,05 & 16.5 & 5.89 & 7.02 & 0.013 & 0.39 & 0.11 \\
\hline LSD 0,01 & 19.8 & 8.05 & 9.08 & 0.017 & 0.60 & 0.17 \\
\hline
\end{tabular}

Table 6. Final fruit number per trunk cross-sectional area, and fruit number, yield and yield efficiency of $>75 \mathrm{~mm}$ fruits of 'Jonathan' apple trees after the application of fruit thinning agents (average 2010-2013).

\begin{tabular}{|c|c|c|c|c|}
\hline Treatment & $\begin{array}{c}\text { Fruit number per } \\
\text { trunk cross- } \\
\text { sectional area }\end{array}$ & $\begin{array}{c}\text { Fruit number } \\
>65 \mathrm{~mm}\end{array}$ & $\begin{array}{l}\text { Yield of }>65 \mathrm{~mm} \\
\text { fruits }\left(\mathrm{kg} \cdot \text { tree }^{-1}\right)\end{array}$ & $\begin{array}{l}\text { Yield efficiency of } \\
>65 \mathrm{~mm}\left(\mathrm{~kg}^{\circ} \mathrm{cm}^{-2}\right)\end{array}$ \\
\hline NAA $15 \mathrm{ppm}$ & 7.2 & 2 & 0.5 & 0.1 \\
\hline NAA $20 \mathrm{ppm}$ & 6.3 & 38 & 7.8 & 1.3 \\
\hline NAA $30 \mathrm{ppm}$ & 4.7 & 26 & 5.6 & 0.9 \\
\hline BA 60 ppm +NAA $5 \mathrm{ppm}$ & 6.1 & 26 & 5.3 & 0.9 \\
\hline BA $100 \mathrm{ppm}+\mathrm{NAA} 5 \mathrm{ppm}$ & 8.6 & 36 & 7.9 & 1.3 \\
\hline BA $120 \mathrm{ppm}+\mathrm{NAA} 5 \mathrm{ppm}$ & 6.3 & 19 & 4.6 & 0.7 \\
\hline BA $140 \mathrm{ppm}+\mathrm{NAA} 5 \mathrm{ppm}$ & 2.9 & 20 & 4.4 & 0.7 \\
\hline Control & 12.1 & 0 & 0 & 0 \\
\hline LSD 0,05 & 0.9 & 3.9 & 0.22 & 0.09 \\
\hline LSD 0,01 & 1.6 & 4.4 & 0.40 & 0.12 \\
\hline
\end{tabular}

resulted in a statistically significant increase of fruit weight had a greater number of fruits and yield of fruits $>75 \mathrm{~mm}$, except for treatment of NAA $20 \mathrm{ppm}$, which was statistically similar to control (Table 4). Individual application of NAA at $15 \mathrm{ppm}$ also resulted in a statistically significant increase in the number and yield of fruits with a diameter $>75 \mathrm{~mm}$, while the average weight of the fruits of this treatment was not significantly different from the control.
Apple cv. Jonathan: The application of NAA and NAA + BA combination of all treatments has led to a statistically significant increase in fruit weight and statistically significant decrease in yield and total number of fruits per trunk crosssectional area in relation to the control (Table 5). Application of $30 \mathrm{ppm}$ NAA and combined application of $120 \mathrm{ppm} \mathrm{BA+}$ NAA $5 \mathrm{ppm}$ resulted in the increase of the fruit shape index (0.93). In all the treatments, except NAA $10 \mathrm{ppm}$, number and 
yield of fruits with a diameter $>75 \mathrm{~mm}$ was significantly higher compared to the control (Table 6). Application of treatments with BA $140 \mathrm{ppm}+$ NAA $5 \mathrm{ppm}$ led to excessive thinning of fruits of 'Jonathan', or a significant reduction in the total number of fruits per trunk cross-sectional area.

Untreated trees of all varieties had a higher number of fruits but with an average weight lower than the fruits from trees with all the applied treatments. In the control treatment in the varieties 'McIntosh' and 'Jonathan' was also obtained higher yield per tree compared to all other treatments. In the cultivar 'Prima' higher yield compared to the control was found after application of combined treatment of BA $100 \mathrm{ppm}+$ NAA 5 ppm. All treatments with applied NAA and NAA + BA had a positive effect on the thinning of fruits in the cultivars 'McIntosh' and 'Jonathan', and among individual treatments were not found statistically significant differences (as seen by the total number of fruits per trunk cross-sectional area).

In the cultivar 'Prima' positive effect on thinning did not achieve in all the treatments, but only a single application treatment of NAA at the concentration of 20 or $30 \mathrm{ppm}$, and the combined use of BA140 ppm + NAA $5 \mathrm{ppm}$. Treatment of NAA at $20 \mathrm{ppm}$ caused significant reduction in the total number of fruits per cross-sectional area of the trunk.

\section{DISCUSSION}

In intensive apple growing systems, chemical fruit thinning is necessary for regulation of crop load and biennial bearing. In order to reduce labor costs, enhance fruit size and return bloom, chemical fruit thinning is a regular practice in apple (Malus $\times$ domestica Borkh.) fruit production (Greene, 2002; Petracek and Silverman, 2003). Abscission of immature fruits occurs frequently, varying in magnitude every year depending on fruit set, climatic conditions during flowering, nutritional status, carbohydrate availability, plant hormonal balance, or any combination of these factors (McArtney, 2005).

Efficacy of chemical thinning, in addition to characteristics of the plant, affect a large number of environmental factors: weather conditions during and after treatment, the training system and cultural practices applied, active ingredient, formulation and concentration of the preparation, added adjuvant, time and method of application (Keserović et al., 2008). In the literature there is information on the effect of different plant regulators on the chemical thinning of apple cultivars from the group of 'Red Delicious' (Marini, 2002; Berlanga Reyes et al., 2008). The lowest fruit set was obtained with naphthalene acetic acid sprayed as chemical thinner in cultivars 'Golden Delicious' and 'RedChief Delicious', and sometimes fruit set was similar to that obtained with early hand-thinning (Berlanga Reyes et al., 2008).

In the experiment, after the treatments, phenomenon of "pigmy" fruits were not observed, which can be explained by the fact that the treatment carried out at the stage of central fruits reached a diameter of $8-10 \mathrm{~mm}$. The similar results in terms of the absence of so-called "pigmy" fruits reported Stopar ( 2002), after the application of single and combined treatments of NAA and BA in chemical thinning of the cultivars 'Golden Delicious' and 'Gala'. Increasing the number of fruits with a diameter $>75 \mathrm{~mm}$ in the cultivar 'McIntosh' was caused by individual application of NAA 15 ppm and combined treatments BA $120 \mathrm{ppm}+$ NAA $5 \mathrm{ppm}$ and BA $140 \mathrm{ppm}+$ NAA $5 \mathrm{ppm}$, while in the cultivar 'Jonathan' most of these fruits was obtained in treatments NAA $20 \mathrm{ppm}$ and $100 \mathrm{ppm}$ BA + NAA $5 \mathrm{ppm}$. In cultivar 'Prima' combined use of BA $60 \mathrm{ppm}+$ NAA $5 \mathrm{ppm}$ and 140 ppm BA + NAA 5 ppm influenced the increase of the number of fruits with a diameter $>65 \mathrm{~mm}$. The results indicate that increasing of the concentration of NAA in the examined commercial cultivars of apples does not contribute to increasing the number of larger fruit.

We consider that the most important aspect of the results of our study can be applied to cultivar 'Jonathan'. We were able to influence the fruit weight of this cultivar, which was followed by an insignificant decrease of total yield. This is of great importance because with our practical work we managed to observe great fruit production of untreated trunks, with the great difference in fruit size.

Conclusion: All applied treatments with NAA and NAA + BA had a positive effect on thinning of apple fruits of the cultivars 'McIntosh' and 'Jonathan', in terms of fruit weight and number of fruits per trunk cross-sectional area. The positive effect of thinning of apple fruit in the 'Prima' cultivar had single application treatments with NAA 20 ppm and NAA $30 \mathrm{ppm}$, and the combined application of BA $140 \mathrm{ppm}+$ NAA $5 \mathrm{ppm}$. In the apple cultivars 'McIntosh' and 'Prima' high efficiency in the thinning showed the combined treatment with BA $140 \mathrm{ppm}+$ NAA $5 \mathrm{ppm}$, as seen through the average weight and number of fruits which fall into the category of large (>75 $\mathrm{mm}$ or $>65 \mathrm{~mm}$ ), and number of fruits per trunk cross-sectional area. In the apple cultivar 'Jonathan' use of combined treatment with BA $100 \mathrm{ppm}+$ NAA $5 \mathrm{ppm}$ has led to the most efficient thinning. Satisfactory effect in the average fruit weight, number of fruits per trunk crosssectional area and the number of fruits with a diameter $>75$ $\mathrm{mm}$ was achieved in cultivar Jonathan after individually applied NAA 20 ppm.

\section{REFERENCES}

Berlanga, R.D.I., A.R. Chacón, Á.R.M. Campos and V.M.G. Prieto. 2008. Apple fruit chemical thinning in Chihuahua, México. Rev. Fitotec. Mex. 31:243-250.

Bound, S.A. 2001. Managing crop load. In: R. Dris, R. Niskanen and S. M. Jain (eds.), Crop Management and Postharvest Handling of Horticultural Products. Inc. Plymouth UK; Science Publisher 1:89-109. 
Bukovac, M.J., B.L. Black, J. Hull and M. Stopar. 1994. Interaction between NAA and BA on cropping and fruit size in 'Delicious' and 'Empire' apples. HortScience 29:472 (Abst.)

Ferree, D.C. 1996. Performance of benzyladenine as a chemical thinner on eight apple cultivars. J. Tree Fruit Prod. 1:33-50.

Greene, D.W., W.R. Autio and P. Miller. 1990. Thinning activity of benzyladenine on several apple cultivars. J. Amer. Soc. Hort. Sci. 115:394-400.

Greene, D.W. 1993. A review of the use of benzyladenine (BA) as a chemical thinner for apples. Acta Hort. 329:231-236.

Greene, D.W. 2002. Chemicals, timing, and environmental factors involved in thinner efficacy on apple. HortScience 37:477-481.

Keserović, Z., B. Vračević, D. Gvozdenović and N. Magazin. 2008. Chemical thinning of fruits of Golden Delicious. J. Pomol. 42:5-9.

Kolke, H, H. Tamai, T. Ono and I. Shigehara. 2003. Influence of time of thinning on yield, fruit quality and return flowering of 'Fuji' apple. J. Amer. Pomol. Soc. 57:169173.

Link, H. 2000. Significance of flower and fruit thinning on fruit quality. Plant Growth Regul. 31:17-26.

Marini, R.P. 1996. Chemically thinning spur 'Delicious' apples with carbaryl, NAA, and ethephon at various stages of fruit development. HortTechnology 6:241-246.

Marini, R.P. 2002. Thinning 'Golden Delicious' and spur 'Delicious' with combinations of carbamates and NAA. HortScience 37:534-538.

McArtney, S. J. 2005. Next steps in crop load management research: escaping vagaries of weather, hormones and carbon balance. The Compact Fruit Tree 38:14-16.
Milić, B., Z. Keserović and N. Magazin. 2011. Production effects of chemical fruit thinning in young apple orchards. Agric. Econ. 58:133-146.

Petracek, P.D. and F.P. Silverman. 2003. A history of commercial plant growth regulators in apple production. HortScience 38:937-942.

Ramirez, H., J. Torres, A. Benavides, J. Hernandez and V. Robledo. 2004. Fruit bud initiation in apple cv. Red Delicious linked to gibberellins and cytokinins. Rev. Soc. Quim. Mex. 48:7-10.

Stopar, M. 2002. Thinning of 'Gala' and 'Golden Delicious' apples with BA, NAA and their combinations. JCEA 3:16.

Stopar M. and V. Lokar. 2003. The effect of ethephon, NAA, $\mathrm{BA}$ and their combinations on thinning intensity of 'Summered'. JCEA 4:399-403.

Stopar, M., and S. Tojnko. 2005. Small fruit appearance on 'Fuji/M.9' apples thinned by the most known thinning agents. Gronn Kunnskap 9:1-4.

Vračević, B., Z. Keserović and N. Magazin. 2008. Influence of chemical thinning increased fruit weight Golden Delicious. Cont. Agri. 57:51-56.

Wertheim, S.J. 1997. Chemical thinning of deciduous fruit trees. Acta Hort. 463:445-462.

Wertheim, S.J. 2000. Developments in the chemical thinning of apple and pear. Plant Growth Regul. 31:85-100.

Wismer, P.T. and J.T.A. Proctor. 1995. Benzyladenine affects cell division and cell size during apple fruit thinning. J. Amer. Soc. Hort. Sci. 120:802-807.

Yuan, R. and D.W. Greene. 2000. Benzyladenine as a chemical thinner for 'McIntosh' apples. I. Fruit thinning effects and associated relationships with photosynthesis assimilate translocation, and nonstructural carbohydrates. J. Amer. Soc. Hort. Sci. 125:169-176. 